1

2

3

\title{
SARS-CoV-2 vaccines breakthrough infection hospitalizations after one dose in Libya: cohort study
}

Mohamed Hadi Mohamed Abdelhamida,b, Iman A. Almsellatic, Badereddin B Annajard, Alaa .H Abdelhamide, Hafsa .A Alemam ${ }^{f}$, Mohammed Etikar ${ }^{\mathrm{a}}$.

a National Center of Disease Control (NCDC), Tripoli - Libya.

b Department of Cell Biology and Tissue Culture, Biotechnology Research Center (BTRC), Tripoli - Libya.

c Primary Health Care, National Center of Disease Control (NCDC), Tripoli - Libya.

${ }^{d}$ Department of Public Health, Faculty of Medical Technology, University of Tripoli, Tripoli 13662, Libya.

e Department of Cardiology, Tripoli University Hospital, Tripoli, Libya.

${ }^{f}$ Department of Environment, Biotechnology Research Center (BTRC), Tripoli - Libya.

4

15

6

17

8

9

0

1

2

3

4

5

6

7


${ }^{*}$ Corresponding author: Mohamed Hadi Mohamed Abdelhamid, National Center of

31 Research Center (BTRC), Tripoli - Libya; Email: Mohamed.abdelhamid@btc.org.ly ;

32 Moh9363@gmail.com Phone N: 00218916030276.

34 Running title: Breakthrough vaccine infection after one dose in Libya.

\section{$37 \quad$ Funding}

38 This research did not receive any specific grant from funding agencies in the public,

39 commercial, or not-for-profit sectors.

40

41

42

43

44

45

46

47

48

49

50

51

52

53

54

55 
medRxiv preprint doi: https://doi.org/10.1101/2021.09.26.21263691; this version posted September 26, 2021. The copyright holder for this preprint (which was not certified by peer review) is the author/funder, who has granted medRxiv a license to display the preprint in perpetuity.

It is made available under a CC-BY-NC-ND 4.0 International license .

56

57

58

59

60

61

62

63

64

65

66 67 of the nation's coronavirus vaccines rollout.

68

69

70

71

72

73

74

75

76

\section{Abstract:} vaccine; Libya

西

2

3

5

6

SARS-CoV-2 infection is widely spread over people, from youth to the elderly. Vaccination against SARS-CoV-2 is an important preventive measurement to help end the SARS-CoV-2 pandemic. From 30 April to 15 July, we collected the number of people infected with SARS-COV-2 and the mortality rate from daily reports issued by the National Center for Disease Control of Libya (NCDC). Approximately 445000 doses have been administered in Libya since 10 April, and 5 thousand doses are now being administered during this period on a daily basis. To estimate the rate of breakthrough vaccine infection of the SARS-COV-2 in Libya. We found that one dose of the three different types of vaccines had decreased the virus transmission across people and mortality rate until 10 weeks after the first dose. This study highlights the dramatic success of the early months

Key Words: SARS-COV-2; Breakthrough vaccines infection; One dose SARS-COV-2 
medRxiv preprint doi: https://doi.org/10.1101/2021.09.26.21263691; this version posted September 26, 2021. The copyright holder for this

preprint (which was not certified by peer review) is the author/funder, who has granted medRxiv a license to display the preprint in perpetuity.

It is made available under a CC-BY-NC-ND 4.0 International license .

\section{Introduction:}

78 SARS-CoV-2 infection is widely spread over people, from youth to the elderly. Mass

79 vaccination operations to prevent coronavirus disease 2019 (Covid-19) are ensuing in

80207 countries; $32 \%$ of the world population has received at least one dose of a SARS-

81 CoV-2 vaccine, and $24 \%$ is fully vaccinated [1]. Approximately 4,84 billion doses have

82 been administered worldwide, and 34,86 million are now administered daily [1,2].

83 Interestingly, SARS-CoV-2 several studies have found that most hospitalizations and

84 deaths due to SARS-CoV-2 infection were among immunocompromised individuals,

85 persons with co-morbidities, elderly and / or unvaccinated people [3-5].

86 Furthermore, previous studies showed that the vaccines reduce the risk of SARS-CoV-2

87 infection, especially illness severity, among partially vaccinated people [6-9] (Table 1).

88 Libya's National Center for Disease Control (NCDC ) reported that the first case of SARS-CoV-2 was identified in Libya on 24 Mars 2020 [10-12]. In addition, as reported by the World Health Organization (WHO), many countries are not very well-prepared to

91 fight the pandemic such as (Libya, Iraq, and Yemen) these countries are more vulnerable

92 to the impact of this pandemic [13].

Nevertheless, In Libya, the national immunization program launched a long-delayed

94 SARS-CoV-2 vaccination program on 10 April 2021, through 400 immunization centers

95 distributor in all cities of the country [12].

96 Currently, most cases of SARS-CoV-2 effects people who have not been fully

97 vaccinated. Over the world, many hospitals have recorded cases of SARS-CoV-2 98 infection in patients after being fully vaccinated, this situation is called a vaccine 
medRxiv preprint doi: https://doi.org/10.1101/2021.09.26.21263691; this version posted September 26, 2021. The copyright holder for this preprint (which was not certified by peer review) is the author/funder, who has granted medRxiv a license to display the preprint in perpetuity.

It is made available under a CC-BY-NC-ND 4.0 International license .

99 breakthrough cases $[2,14]$. Although SARS-CoV-2 vaccines right now appear to be very

100 effective against the disease severity and deaths, no vaccine is perfect [15].

101 Furthermore, two studies in Scotland and England confirm high protection rates (80\%$10291 \%)$ after the first dose of Pfizer or Oxford/AstraZeneca vaccines [3,4]. Previous studies 103 have found that a single dose of the Sputnik V vaccine may be enough to elicit a strong 104 antibody response against SARS-CoV-2 [16,17]. However, In the United States, the U.S.

105 Center for Disease Control and Prevention (CDC) reported a total of 10,262 SARS-CoV1062 vaccine breakthrough infections from 46 U.S. states and territories as of April 30, $1072021[18]$. A recent study reported that the effectiveness of the vaccines against infections 108 had decreased from $91.7 \%$ to $79.8 \%$ between 3 May and 25 July in New York [19]. 109 Additionally, a study published by National Healthcare Safety Network (NHSN) found that 110 the two mRNA (nucleoside-modified) vaccines (Pfizer-BioNTech and Moderna) were 111 effective by $74.7 \%$ in nursing home residents between March and May, however, the 112 protection has declined to $53.1 \%$ between June and July[20].

Investigating the trend of SARS-CoV-2 infection severity, hospitalizations rate, and 114 deaths among persons who got the first dose of the SARS-CoV-2 vaccine are urgently 115 needed to support decision-making logistics such as cold chains, vaccination schedules, 116 and follow-up. 
medRxiv preprint doi: https://doi.org/10.1101/2021.09.26.21263691; this version posted September 26, 2021. The copyright holder for this preprint (which was not certified by peer review) is the author/funder, who has granted medRxiv a license to display the preprint in perpetuity.

It is made available under a CC-BY-NC-ND 4.0 International license .

\section{Material and methods}

122 We collected SARS-CoV-2 infection and mortality rate data by the NCDC daily reports

123 from 30 April 2021 until 15 July 2021. The study includes all patients who were admitted

124 to hospitals with confirmed SARS-CoV-2 by repeat reverse-transcriptase-polymerase-

125 chain-reaction assays (RT-PCR). The data were collected from the medical record of the 126 patients by intensive care physicians and healthcare centers staff working in 34

127 healthcare centers and hospitals from different cities. Inclusion criteria were all vaccinated 128 and unvaccinated cases admitted to the healthcare centers during this period. 129 Concurrently, we tracked the number of people who received the first dose of the SARS130 CoV-2 vaccine since 10 April 2021.

\section{Ethics statement}

132 The study was approved by the Ethics Committee (National committee for Biosafety and Bioethics at Biotechnology Research Center, Tripoli - Libya, No: BTRC- 2021).

First Dose of COVID-19 Vaccines:

As the emergence of the new variant strains of SARS-CoV-2 B.1.617.2 (Delta) in the world in December 2020, they have led to a rapid increase in the circulation of the virus and a rising demands for vaccines.

UNICEF, through COVID-19 Vaccines Global Access (COVAX), supported the Libyan government by delivering 57,600 doses at 8 April 2021[21]. Also, as an intranational gift

141 the Libya government received an around 200,000 doses of (Sputnik V) vaccines, and 142150,000 doses of Sinovac vaccine on April 2021[12]. Thus, a countrywide mass 143 vaccination campaign with the use of three different authorized vaccines 
144 (Oxford/AstraZeneca, Sinovac, Sputnik V) was conducted in Libya starting from 10 April, 1452021 [22]. Nearly 5000 doses were administered daily through 400 immunization centers

146 in all cities of the country. So far, about 445,000 people have received the first dose of

147 vaccines that provided by the national immunization program. Priority was given to 148 frontline healthcare and hospitals workers, adults over 60, and patients with chronic 149 underlying health conditions in all regions of the country.

150 Hance, 110,000 doses of Sinovac, 175,000 doses of Oxford/AstraZeneca, and 160,000 151 doses of Sputnik V were administered. The National Center for Disease Control (NCDC) 152 has recommended that the Oxford/AstraZeneca vaccine to be used for people aged over 15355 years old. The other vaccines (Sinovac and Sputnik V) to be used for people who is 15416 years old or more.

155 Moreover, due to delays in providing vaccines throughout COVAX and countries who 156 are producing the vaccines, the NCDC announced a deviation from the recommended 157 protocol for the SARS-CoV-2 vaccines, prolonging the interval between doses from 2 to 1584 months. This procedure had two advantages: The first, a longer gap between doses 159 may improve the long-term immune response, as demonstrated by AstraZeneca's 160 vaccine[5]. Secondly, a larger number of elderly and people with chronic diseases will be 161 vaccinate.

\section{Hospital Admissions after one dose of vaccines}

163 As of 15 July 2021, approximately 445000 persons in Libya had been received the first 164 dose of the SARS-CoV-2 vaccines. 
According to the NCDC data from 30 April 2021 (W1) to 15 July 2021 (W22), the total number of patients who have a confirmed SARS-CoV-2 infection is 39996. 3179 out of

167 the total $(7.9 \%)$ were admitted to healthcare centers, and among those 226 patients $168(7.10 \%)$ died during this period.

At the same time, A total of 43 SARS-CoV-2 vaccine breakthrough infections (i.e. One dose obtained from the vaccine) were reported from 18 healthcare centers and hospitals

171 as of 30 April 2021. Among these cases, 8 patients died. Patients in healthcare seem to 172 be moving towards an average age of around 55-87 years old (Table 2). Notably, 23 173 patients who were admitted to healthcare centers are vaccinated with the CoronaVac 174 (Sinovac) vaccine. 14 patients received the Oxford/AstraZeneca. While only two patients 175 had the Sputnik V vaccine.

176 Of 445000 people who had taken the first dose of the vaccines, the percentage of 177 patients who had been admitted to the healthcare centers, and died is very low $(0.009$, $178 \quad 0.001 \%)$ respectively.

Since July, the NCDC has reported initial evidence that people being infected with the 180 Delta variant. Where the numbers testing positive increased five-fold, from 1600 the 181 previous week to 15000 cases. It recorded its highest number of cases on 12 July (W20). 182 However, the number of patients' deaths remains lower compared to W11 (17-26 patients 183 per day) (Fig.1).

184 In this period (W20), with delays in travel restrictions, there has been a significant 185 increase in the number of people confirmed with SARS-CoV-2. Particularly in the western 186 cities such as (Zawiya, Tripoli, Shakshok, Zliten, and Misrata), due to proximity to the 
medRxiv preprint doi: https://doi.org/10.1101/2021.09.26.21263691; this version posted September 26, 2021. The copyright holder for this preprint (which was not certified by peer review) is the author/funder, who has granted medRxiv a license to display the preprint in perpetuity.

It is made available under a CC-BY-NC-ND 4.0 International license .

187 Tunisian borders, which was recording the peak of infection rates in Africa and in the 188 world with Delta variant (Fig 2).

$189 \quad$ Limitations of study

190 The results in this study are subject to two limitations, the first one, that the number of 191 reported SARS-CoV-2 vaccine breakthrough cases is substantially lower than that of all 192 SARS-CoV-2 infections among one dose vaccinated persons. However, many people 193 with vaccine breakthrough infections, especially those who are asymptomatic or who 194 experience mild illness, might not seek testing. The second, SARS-CoV-2 sequence data 195 are available for only a small proportion of the reported cases.

\section{Conclusion}

197 In the present study, one dose of the three different types of vaccines had showed a 198 decreasing in infection and mortality rate. The results were very encouraging. However, 199 all these results were before the delta variant entered Libya. So as a recommendation, 200 the department of health and NCDC must focus and make all possible efforts to get as 201 many people vaccinated within a short period of time to prevent the development of new 202 virus variants.

\section{Acknowledgements}

204 The authors wish to thank all doctors in healthcare centers and hospitals who were 205 involved in this study, and Hamza El-thelb for editing the text.

207 Conflicts of interest: The authors have declared that no competing interests exist. 
medRxiv preprint doi: https://doi.org/10.1101/2021.09.26.21263691; this version posted September 26, 2021. The copyright holder for this preprint (which was not certified by peer review) is the author/funder, who has granted medRxiv a license to display the preprint in perpetuity.

It is made available under a CC-BY-NC-ND 4.0 International license .

\section{Contributors:}

210 (I)Manuscript writing: All authors; (II) Final approval of manuscript: All authors.

211

212

213

214

215

216

217

218

219

220

221

222

223

224

225

226 
227

228

229

230

231

232

233

234

235

236

237

238

239

240

241

242

243

244

245

246

247

248

\section{Reference}

1. Hannah Ritchie, Edouard Mathieu, Lucas Rodés-Guirao, Cameron Appel, Charlie Giattino, Esteban Ortiz-Ospina, Joe Hasell, Bobbie Macdonald DB and MR. Coronavirus Pandemic (COVID-19). OurWorldlnData.org. 2021. Available: https://ourworldindata.org/covid-vaccinations\#citation

2. Jara A, Undurraga EA, González C, Paredes F, Fontecilla T, Jara G, et al. Effectiveness of an Inactivated SARS-CoV-2 Vaccine in Chile. N Engl J Med. 2021; 1-11. doi:10.1056/nejmoa2107715

3. Bernal JL, Andrews N, Gower C, Stowe J, Robertson C, Tessier E, et al. Early effectiveness of COVID-19 vaccination with BNT162b2 mRNA vaccine and ChAdOx1 adenovirus vector vaccine on symptomatic disease, hospitalisations and mortality in older adults in England. medRxiv. 2021; 2021.03.01.21252652. Available: https://doi.org/10.1101/2021.03.01.21252652

4. Vasileiou E, Simpson CR, Shi T, Kerr S, Agrawal U, Akbari A, et al. Interim findings from first-dose mass COVID-19 vaccination roll-out and COVID-19 hospital admissions in Scotland: a national prospective cohort study. Lancet. 2021;397: 1646-1657. doi:10.1016/S0140-6736(21)00677-2

5. lacobucci G, Mahase E. Covid-19 vaccination: What's the evidence for extending the dosing interval? BMJ. 2021;372: n18. doi:10.1136/bmj.n18

6. Swan DA, Bracis C, Janes H, Moore M, Matrajt L, Reeves DB, et al. COVID-19 vaccines that reduce symptoms but do not block infection need higher coverage and faster rollout to achieve population impact. Sci Rep. 2021;11: 1-9. 
doi:10.1038/s41598-021-94719-y

7. Mallapaty BS. COVID VACCINES SLASH VIRAL SPREAD - BUT.

251 8. Baden LR, El Sahly HM, Essink B, Kotloff K, Frey S, Novak R, et al. Efficacy and Safety of the mRNA-1273 SARS-CoV-2 Vaccine. N Engl J Med. 2021;384: 403-

9. Harris RJ, Hall JA, Zaidi A, Andrews NJ, Dunbar JK, Dabrera G. Effect of 255 Vaccination on Household Transmission of SARS-CoV-2 in England. N Engl J Med. 2021;385: 759-760. doi:10.1056/nejmc2107717

257 10. Bredan A, Bakoush O. COVID-19 epidemic in Libya. Libyan J Med. 2021;16. doi:10.1080/19932820.2021.1871798

11. Rayes AA, Annajar BB, Dayhum AS, Eldaghayes IM. Why there were few cases of coronavirus disease 2019 in Libya during the first two months of the pandemic? Int J One Heal. 2020;6: 160-164. doi:10.14202/IJOH.2020.160-164

12. Mahmoud AS, Dayhum AS, Rayes AA, Annajar BB, Eldaghayes IM. Exploiting epidemiological data to understand the epidemiology and factors that influence COVID-19 pandemic in Libya. World J Virol. 2021;10: 156-167. doi:10.5501/wjv.v10.i4.156

13. Gasibat Q, Raba AA, Abobaker A. COVID-19 in Libya, fewer cases so far. Any speculations? Disaster Med Public Health Prep. 2020; 2020-2021. doi:10.1017/dmp.2020.177 
271

272

273

274

275

276

277

278

279

19 in vaccinated United States Veterans with spinal cord injuries and disorders.

Spinal Cord. 2021; 1-2. doi:10.1038/s41393-021-00690-w

15. Dye C, Mills MC. COVID-19 vaccination passports. Science (80- ). 2021;371. doi:10.1126/science.abi5245

16. Rossi AH, Ojeda DS, Varese A, Sanchez L, Gonzalez Lopez Ledesma MM, Mazzitelli I, et al. Sputnik V vaccine elicits seroconversion and neutralizing capacity to SARS-CoV-2 after a single dose. Cell Reports Med. 2021;2. doi:10.1016/j.xcrm.2021.100359

17. Claro F, Silva D, Rodriguez M, Rangel R, de Waard JH. IgG Antibody response to the Sputnik V vaccine: previous SARS-CoV-2 seropositive individuals might need just one vaccine dose. Int J Infect Dis. 2021; 0-21. doi:10.1016/j.jij.2021.07.070

18. CDC. COVID-19 Vaccine Breakthrough Infections Reported to CDC - MMWR Morb Mortal Wkly Rep. 2021;70: 792-793.

19. Rosenberg ES, Holtgrave DR, Dorabawila V, Conroy M, Greene D. New COVID19 Cases and Hospitalizations Among Adults, by Vaccination Status - New York , May 3 - July $25,2021.2021 ; 70$.

20. Nanduri S, Pilishvili T, Derado G, Soe MM, Dollard P, Wu H. Effectiveness of Pfizer-BioNTech and Moderna Vaccines in Preventing SARS-CoV-2 Infection Among Nursing Home Residents Before and During Widespread Circulation of the SARS-CoV-2 B . 1 . 617 . 2 (Delta) Variant — National Healthcare Safety Network, March. 2021;70: 1163-1166. 
medRxiv preprint doi: https://doi.org/10.1101/2021.09.26.21263691; this version posted September 26, 2021. The copyright holder for this preprint (which was not certified by peer review) is the author/funder, who has granted medRxiv a license to display the preprint in perpetuity. It is made available under a CC-BY-NC-ND 4.0 International license .

291 21. Situation H, No R, Status F, Appeal U. Libya Country Office. 2021; 1-10.

292 22. NDCD. weekly updet of COVID-19 Libya. In: NCDC Libya [Internet]. 2021 pp. 1-

293 5. Available: https://ncdc.org.ly/Ar/

294

295

296

297

298

299

300

301

302

303

304

305

306

307

308

309 


\section{Table and Figure legend}

311 Table 1

312 The efficacy of the vaccines against symptomatic, severe, and hospitalization SARSCoV-2 infection.

\section{Table 2}

315 Numbers of patients who were admitted to healthcare centers or hospitals after received

316 one dose of vaccine in Libya. N: Number DM: Diabetic HT: Hypertension

317 CoronaVac: Sinovac Astra: Oxford/AstraZeneca SputV: Sputnik v $(-)=$ Data not 318 available.

\section{Figure 1}

320 Number of patients confirmed SARS-COV-2 Infection from February to 15 July in Libya. 321 Green ring: start to vaccines program Red ring: first cases with Delta variant.

\section{$322 \quad$ Figure 2}

323 The geographic distribution of SARS-COV-2 infection in Libya. 
medRxiv preprint doi: https://doi.org/10.1101/2021.09.26.21263691; this version posted September 26, 2021. The copyright holder for this preprint (which was not certified by peer review) is the author/funder, who has granted medRxiv a license to display the preprint in perpetuity. It is made available under a CC-BY-NC-ND 4.0 International license .

330 Table 1. shows the efficacy of the vaccines against symptomatic, severe, and hospitalization SARS-CoV-2 infection.

\begin{tabular}{|c|ccc|}
\hline Vaccines & SARS-CoV-2 infection & $\begin{array}{c}\text { Against } \\
\text { vaccines against symptoms } \\
\text { SAR-CoV-2 after receiving } \\
\text { the first dose }\end{array}$ & $\begin{array}{c}\text { hospitalization } \\
\text { after receiving } \\
\text { the first dose }\end{array}$ \\
AstraZeneca & $67 \%$ & $68.7 \%$ & $76 \%$ \\
Sputnik-V & $80 \%$ & $81 \%$ & $87 \%$ \\
CoronaVac & $49.6 \%$ & $70 \%$ & $99.2 \%$ \\
\hline
\end{tabular}

332 
medRxiv preprint doi: https://doi.org/10.1101/2021.09.26.21263691; this version posted September 26, 2021. The copyright holder for this preprint (which was not certified by peer review) is the author/funder, who has granted medRxiv a license to display the preprint in perpetuity.

It is made available under a CC-BY-NC-ND 4.0 International license .

Table 2. Numbers of patients who were admitted to healthcare centers or hospitals after received one dose of vaccine in Libya

\begin{tabular}{|c|c|c|c|}
\hline $\mathbf{N}$ & Healthcare center & $\mathbf{N}$ of patient (Type of vaccines) & $\mathrm{N}$ of died (Type of vaccine) \\
\hline \multirow{2}{*}{1} & & 2 (CoronaVAC) & \multirow{2}{*}{1 (Astra) } \\
\hline & & 1 (Astra) & \\
\hline 2 & Marj & 2 (CoronaVac) & 0 \\
\hline 3 & Bayda & 1 (CoronaVac) & 0 \\
\hline 4 & Sabha & 1 (Astra) & 1 (Astra) \\
\hline \multirow{3}{*}{5} & \multirow{3}{*}{ Tripoli1 } & 1 (Astra) & \multirow{3}{*}{1 (CoronaVac) } \\
\hline & & 1 (CoronaVac) & \\
\hline & & 1 (Sput V) & \\
\hline 6 & Tripoli 2 & - & - \\
\hline 7 & Zliten & 3 (Astra) & 0 \\
\hline 8 & Zawiya & - & - \\
\hline 9 & Misrata & - & 0 \\
\hline \multirow{2}{*}{10} & \multirow{2}{*}{ Zuwara } & 2 (CoronaVac) & \multirow{2}{*}{1 (CoronaVac) } \\
\hline & & 1 (Astra) & \\
\hline 11 & Tegy & 1 (Astra) & 0 \\
\hline 12 & Tobruq & 2 (CoronaVac) & 1 (Corona Vac) \\
\hline \multirow{2}{*}{13} & \multirow{2}{*}{ Ghadames } & 2 (CoronaVac) & \multirow{2}{*}{0} \\
\hline & & 1 (Astra) & \\
\hline 14 & Benghazi & 2 (Astra) & 0 \\
\hline 15 & Shakshok & 2 (CoronaVac) & 1 (CoronaVac) \\
\hline 16 & Msallata & 3 (CoronaVac) & 1 (CoronaVac) \\
\hline \multirow{2}{*}{17} & \multirow{2}{*}{ Khoms1 } & 1 (CoronaVac) & \multirow{2}{*}{0} \\
\hline & & 1 (Astra) & \\
\hline \multirow{3}{*}{18} & \multirow{4}{*}{ Khoms2 } & 1 (Sput V) & \multirow{3}{*}{1 (CoronaVac) } \\
\hline & & 3 (CoronaVac) & \\
\hline & & 2 (Astra) & \\
\hline & & Total $\mathrm{N}$ of patient $=\mathbf{4 3}$ & Total $\mathbf{N}$ of patient Died $=8$ \\
\hline
\end{tabular}




\section{Fig 1. Number of patients who confirmed SARS-COV-2 Infection}

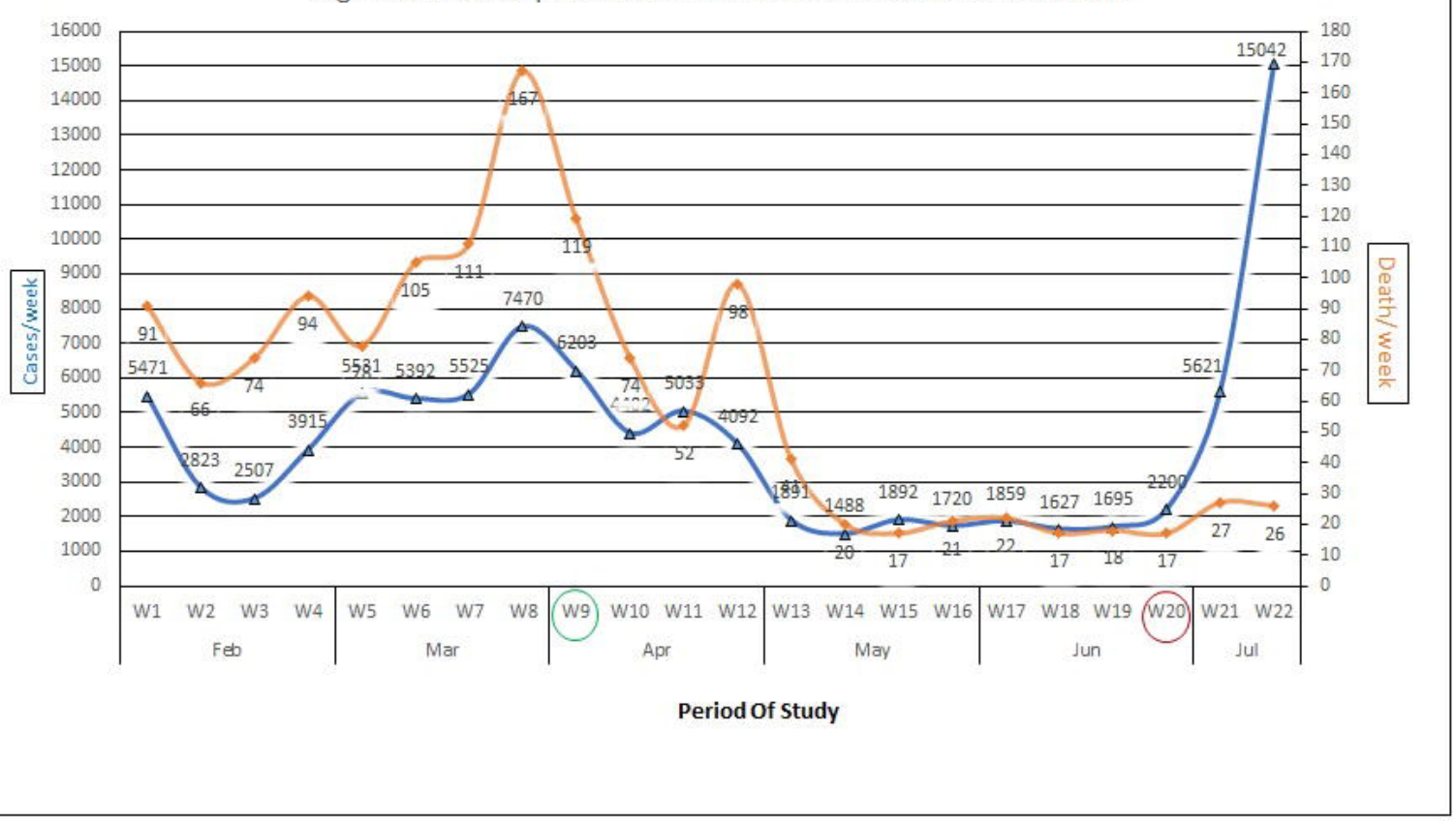




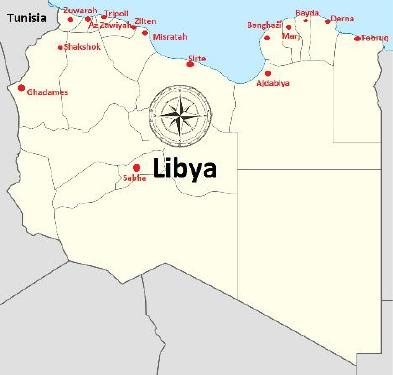

